four of the nine abnormal patients received oxytocin. The figures in the Table do not suggest any difference between those who were treated with oxytocin and those who were not.

Our results are compatible with the belief (Rydén, 1966; Page et al., 1961) that the plasma oxytocinase is mainly derived from the placenta. Schmorl (1893), and more recently Hamilton and Boyd (1966), have described in the human the separation of portions of syncytial trophoblast ("sprouts") and their entry into the maternal blood stream. If, as seems possible, this process of discharge of syncytial sprouts is increased when labour is prolonged, and if, as has been suggested (Ross, 1961), the syncytial trophoblast is the origin of placental oxytocinase, then prolonged labour would be likely to increase the activity of the plasma at the expense of the placenta. We are doing further experiments to test this hypothesis.

We are grateful to Mr. Arthur Williams for supplying us with material from patients under his care in the Nuffield Department of Obstetrics and Gynaecology, Oxford, and for helpful information about deportation of trophoblast.

\section{REFERENCES}

Babuna, C., and Yenen, E. (1966). Amer. 7. Obstet. Gynec., 94, 868.

Fylling, P. (1964). Acta obstet. gynec. scand., 43, 103.

Gaddum, J. H. (1953). Brit. F. Pharmacol., 8, 321.

Hamilton, W. J., and Boyd, J. D. (1966). Brit. med. 7., 1, 1501.

Lambrinopoulos, T. C. (1964). Obstet. and Gynec., 23, 780.

Lowry, O. H., Rosebrough, N. J., Farr, A. L., and Randall, R. J. (1951). 7. biol. CChem., 193, 265.

Melander, S. E. J. (1965). Acta endocr. (Kbh.), 48, Suppl. No. 96, p. 1. Munsick, R. A. (1960). Endocrinology, 66, 451.

Page, E. W., Titus, M. A., Mohun, G., and Glendening, M. B. (1961). Amer. Ұ. Obstet. Gynec., 82, 1090.

Riad, A. M. (1966). F. Obstet. Gynaec. Brit. Cwlth, 73, 977.

Ross, R. A. (1961). Amer. 7. Obstet. Gynec., 82, 1094.

Rydén, G. (1966). Acta obstet. gynec. scand., 45, Suppl. No. 3.

Schmorl, G. (1893). Pathologische-anatomische Untersuchungen über Puerperal-Eklampsie. Leipzig.

\title{
Cardiac Manifestations During a Coxsackie B5 Epidemic
}

\author{
M. HELIN,* M.D.; J. SAVOLA,* M.D. ; KAISA LAPINLEIMU, $\dagger$ M.D.
}

\begin{abstract}
Cummary : During a widespread Coxsackie B5 $S$ epidemic which occurred in Finland in the autumn of 196518 patients with acute myopericarditis were admitted to Kuopio Central Hospital (530 beds, representing a hospital district with 270,000 inhabitants) within a period of three months.
\end{abstract}

The mean age of these patients was 28 years. Twelve were males and six were females.

In 12 cases Coxsackie B5 virus and in one case Coxsackie $A 9$ virus were isolated from the faeces. A significant increase in neutralizing antibodies or high antibody titres ( $\geqslant 1: 128$ ) were noted in 16 cases against Coxsackie B5 and in one case against Coxsackie A9. In two cases the cause of the myopericarditis remained obscure.

All the patients had fever. Six showed all classical criteria of pericarditis : chest pain, pericardial rub, E.C.G. changes, and radiologically observable enlargement of the heart. As regards the various criteria, E.C.G. changes were found in all cases. Signs of cardiac tamponade were observed in one patient. Five, in addition, showed aseptic meningitis.

All the patients recovered. Twelve were re-examined at an average of seven months after discharge from hospital. All were symptom-free except one, who still showed E.C.G. changes.

\section{Introduction}

Interest in infections caused by Coxsackie B viruses has increased since improved techniques have made it possible to identify the causative factors in viral diseases. The most typical clinical conditions caused by them are pleurodynia, myalgia, aseptic meningitis, and pericarditis.

As long ago as the beginning of the last century certain cases of febrile disease resembling pleurodynia were reported in which pericarditis and exanthema were also observed (Jarcho, 1963). When pleurodynia, or Bornholm disease, reached epidemic proportions in Scandinavia in the 1930s, pericarditis was

* Central Hospital, Kuopio, Finland.

†Virological Laboratory, State Serum Institute, Helsinki. frequently an associated feature (Bing, 1933). In the 1950s, after Coxsackie B viruses had been discovered to be the cause of Bornholm disease, an obvious correlation was detected between these viruses and infectious heart diseases. The first observations were made on newborn infants with acute myocarditis in 1952 (Javett et al., 1956), and on adults with socalled acute benign pericarditis in 1957 (Fletcher and Brennan, 1957; Weinstein, 1957). Subsequently, numerous cases of pericarditis or myocarditis caused by Coxsackie viruses have been described (Smith, 1966).

The present paper is a report on 18 patients with carditis who, during a Coxsackie B5 epidemic occurring in Finland in 1965 , were all treated in the same hospital within a period of three months.

\section{Material}

Clinical Data.-In the latter half of 1965 a widespread epidemic due to Coxsackie B5 occurred in Finland. During this time a large number of patients with pleurodynia and/or meningoencephalitis were investigated at the outpatient department of the Kuopio Central Hospital (530 beds). The hospital district comprises 270,000 inhabitants in $16,700 \mathrm{sq}$. km. Only the most severely ill of these patients were admitted to hospital: aseptic meningitis 20 cases, carditis 18 , pleurodynia 10 , encephalitis 6 . The 18 patients (12 males, 6 females) with carditis (Table I) were mostly young adults-mean age 28 years. The mean interval between the onset of signs and symptoms and admission to hospital was 10 days. The preadmission diagnosis included pericarditis in six cases, cardiac infarction in one, acute appendicitis in one, pleurisy in one, congenital heart disease in two, endocarditis in two, acute infection in one, meningitis in one, and pleurodynia in three cases. Precordial pain, aggravated by movement and respiration, had been present in 12 cases. Two patients had experienced dyspnoea, and one had observed oedema before admission to hospital.

Virological Methods.-Virus isolations were performed in tissue cultures of primary human amnion cells, U-cells (a continuous amnion line), and monkey kidney cells. Typing was also made in tissue cultures, the neutralization test 
TABle I.-Clinical Data of Patients with Myopericarditis

\begin{tabular}{|c|c|c|c|c|c|c|c|c|c|c|c|c|c|}
\hline $\begin{array}{l}\text { Case } \\
\text { No. }\end{array}$ & Age & Sex & $\begin{array}{c}\text { Onset } \\
\text { Before } \\
\text { Admission }\end{array}$ & $\begin{array}{l}\text { Days in } \\
\text { Hospital }\end{array}$ & $\begin{array}{c}\text { Pre- } \\
\text { cordial } \\
\text { Pain }\end{array}$ & $\begin{array}{c}\text { Tem- } \\
\text { perature }\end{array}$ & $\begin{array}{c}\text { Pericordial } \\
\text { Friction } \\
\text { Rub }\end{array}$ & E.S.R. & $\begin{array}{l}\text { Leuco- } \\
\text { cytes }\end{array}$ & A.S.T. & $\begin{array}{l}\text { E.C.G. } \\
\text { Changes }\end{array}$ & $\begin{array}{c}\text { Heart } \\
\text { Size on } \\
X \text {-ray } \\
\text { Film }\end{array}$ & Comments \\
\hline $\begin{array}{r}1 \\
2 \\
3 \\
4 \\
5 \\
6 \\
7 \\
8 \\
9 \\
10 \\
11 \\
12 \\
13 \\
14 \\
15 \\
16 \\
17 \\
18\end{array}$ & $\begin{array}{r}32 \\
16 \\
45 \\
19 \\
35 \\
19 \\
42 \\
8 \\
9 \\
9 \\
26 \\
54 \\
16 \\
26 \\
26 \\
65 \\
26 \\
16 \\
35\end{array}$ & $\begin{array}{l}M \\
M \\
M \\
\mathbf{F} \\
\mathbf{M} \\
\mathbf{M} \\
\mathbf{M} \\
\mathbf{F} \\
\mathbf{M} \\
\mathbf{F} \\
\mathbf{M} \\
\mathbf{M} \\
\mathbf{M} \\
\mathbf{F} \\
\mathbf{F} \\
\mathbf{M} \\
\mathbf{F} \\
\mathbf{M}\end{array}$ & $\begin{array}{r}14 \\
21 \\
5 \\
11 \\
8 \\
25 \\
14 \\
10 \\
1 \\
21 \\
14 \\
10 \\
6 \\
1 \\
1 \\
14 \\
5 \\
4\end{array}$ & $\begin{array}{l}11 \\
30 \\
28 \\
13 \\
25 \\
19 \\
18 \\
14 \\
34 \\
23 \\
27 \\
28 \\
23 \\
11 \\
21 \\
27 \\
14 \\
17\end{array}$ & $\begin{array}{l}\bar{t} \\
+ \\
+ \\
+ \\
+ \\
+ \\
+ \\
+ \\
+ \\
+ \\
+ \\
+ \\
+ \\
+\end{array}$ & $\begin{array}{c}37 \cdot 6 * \\
38 \cdot 1 \\
37 \cdot 6 \\
38 \cdot 2 \\
38 \cdot 7 \\
37 \cdot 3 \\
38 \cdot 2 \\
38 \cdot 6 \\
37 \cdot 5 \\
t \\
37 \cdot 5 \\
39 \cdot 0 \\
t \\
39 \cdot 2 \\
38 \cdot 8 \\
37 \cdot 8 \\
37 \cdot 5 \\
t\end{array}$ & $\begin{array}{l}- \\
+ \\
- \\
+ \\
+ \\
+ \\
+ \\
+ \\
+ \\
+ \\
+ \\
+ \\
+ \\
+ \\
+ \\
+\end{array}$ & $\begin{array}{l}17^{*} \\
47 \\
48 \\
20 \\
23 \\
33 \\
30 \\
47 \\
22 \\
69 \\
93 \\
84 \\
23 \\
77 \\
115 \\
92 \\
38 \\
25\end{array}$ & $\begin{array}{r}6,100^{*} \\
18,000 \\
6,600 \\
5,400 \\
13,000 \\
9,700 \\
14,800 \\
12,600 \\
9,600 \\
6,300 \\
6,200 \\
14,400 \\
7,100 \\
9,600 \\
6,000 \\
19,600 \\
5,900 \\
14,100\end{array}$ & $\begin{array}{c}200^{*} \\
50 \\
160 \\
200 \\
100 \\
320 \\
160 \\
\text { Not done } \\
\text { Not done } \\
80 \\
640 \\
160 \\
200 \\
200 \\
100 \\
200 \\
1,600 \\
80\end{array}$ & $\begin{array}{c}\text { RS-T } \\
\text { RS-T } \\
\text { RS-T } \\
T \\
T \\
T \\
\text { RS-T } \\
T \\
T \\
T \\
T \\
T \\
\text { RS-T } \\
\text { RS-T } \\
T \\
\text { RS-T } \\
\text { RS-T } \\
\text { RS-T }\end{array}$ & $\begin{array}{c}\text { Norm. } \\
+\ddagger \\
+ \\
\text { Norm. } \\
\text { Norm. } \\
+ \\
\text { Norm. } \\
\text { Norm. } \\
\text { Norm. } \\
+ \\
+ \\
+ \\
\text { Norm. } \\
\text { Norm. } \\
+ \\
+ \\
+ \\
\text { Norm. } \\
\text { Norm. }\end{array}$ & $\begin{array}{l}\text { Aseptic meningitis } \\
\text { Pleural friction rub } \\
\text { Pleural friction rub } \\
\text { Cardiac decompensation } \\
\text { Tamponade. Pleural effusion } \\
\text { Aseptic meningitis } \\
\text { S.G.O.T. } 41 \text { u. Pleural effusion }\end{array}$ \\
\hline
\end{tabular}

* Highest value recorded at hospital. + Fever subsided before admission. $\ddagger=$ Enlarged.

being used. Antibody response was studied by means of the neutralization test: twofold serial dilutions of paired sera were allowed to react at room temperature for two hours with an equal volume of the prototype strain of the virus to be tested, containing $100 \mathrm{ID}_{50}$ per $0.1 \mathrm{ml}$. The highest dilution of the serum neutralizing the standard dose of the virus was taken as the antibody titre.

\section{Results}

The age and sex of the patients, the duration of symptoms before admission, the length of stay in hospital, and the results of the most important clinical examinations are shown in Table I.

The E.S.R. was elevated in all cases. Leucocytosis $(>10,000 / \mathrm{cu}$. mm.) was present in seven cases; the highest leucocyte count was 19,600 . No leucopenia was observed. A differential leucocyte count was made in 15 cases, neutrophilia being detected in seven while the result was normal in eight.

The S.G.O.T. was markedly raised in one patient (Case 4)to 79 S.F. units-and slightly elevated in one (Case 18)-to 41 units. The antistreptolysin titre (A.S.T.) was raised $(>200$ units) in three cases and markedly raised, to 1,600 , in one (Case 17). The antibody titres against Toxoplasma and the commonest strains of Leptospira were measured, but no increased values were noted.

A pericardial rub was heard in 14 patients and a pleural rub was observed in two (Cases 11 and 12). Clinical symptoms of cardiac insufficiency were present in two patients (Cases 15 and 16). Signs of cardiac tamponade were observed in one patient (Case 16). Electrocardiographic changes were found in all cases-RS- $T$ changes in nine and $T$ changes alone in nine. On radiological investigation the heart shadow was found to

TABLE II.-Virological Studies in Patients with Myopericarditis

\begin{tabular}{|c|c|c|c|c|c|c|c|c|c|}
\hline \multirow{3}{*}{ Case } & \multirow{3}{*}{ Age } & \multirow{3}{*}{ Sex } & \multirow{3}{*}{$\begin{array}{c}\text { Isolation } \\
\text { from } \\
\text { Faeces }\end{array}$} & \multicolumn{6}{|c|}{ Neutralizing Antibodies Against } \\
\hline & & & & \multicolumn{2}{|c|}{ Coxs. B5 } & \multicolumn{2}{|c|}{ Coxs. A9 } & \multicolumn{2}{|c|}{ Coxs. B3 } \\
\hline & & & & Acute & Conv. & Acute & Conv. & Acute & Conv. \\
\hline $\begin{array}{r}1 \\
2 \\
3 \\
4 \\
5 \\
6 \\
7 \\
8 \\
9 \\
10 \\
11 \\
12 \\
13 \\
14 \\
15 \\
16 \\
17 \\
18\end{array}$ & $\begin{array}{r}32 \\
16 \\
45 \\
19 \\
35 \\
19 \\
42 \\
8 \\
9 \\
26 \\
54 \\
16 \\
26 \\
26 \\
65 \\
26 \\
16 \\
35\end{array}$ & $\begin{array}{l}M \\
M \\
M \\
F \\
M \\
M \\
M \\
F \\
M \\
F \\
M \\
M \\
M \\
F \\
F \\
M \\
F \\
M\end{array}$ & $\begin{array}{l}\text { Coxs. B5 } \\
\text { Coxs. B5 } \\
\text { Coxs. B5 } \\
\text { Coxs. B5 } \\
\text { Coxs. B5 } \\
\text { Coxs. B5 } \\
\text { Coxs. B5 } \\
\text { Coxs. B5 } \\
\text { 二 } \\
\text { Coxs. A9 } \\
\text { Coxs. B5 } \\
\text { Coxs. B5 } \\
\text { Coxs. B5 } \\
= \\
\text { Coxs. B5 } \\
\end{array}$ & $\begin{array}{c}64^{*} \\
512 \\
<8 \\
512 \\
128 \\
512 \\
128 \\
128 \\
64 \\
512 \\
256 \\
1,024 \\
512 \\
\text { N.A. } \\
\text { N.A. } \\
\text { N.A. } \\
256 \\
<8\end{array}$ & $\begin{array}{r}256 \\
>1,024 \\
>256 \\
1,024 \\
512 \\
1,024 \\
>1,024 \\
256 \\
128 \\
512 \\
256 \\
>1,024 \\
512 \\
1,024 \\
32 \\
512 \\
256 \\
<8\end{array}$ & $\begin{array}{r}<4 \\
<4 \\
<4 \\
<4 \\
<4 \\
<4 \\
<4 \\
<4 \\
<4 \\
<4 \\
64 \\
<4 \\
16 \\
\text { N.A. } \\
\text { N.A. } \\
\text { N.A. } \\
<4 \\
32\end{array}$ & $\begin{array}{l}<4 \\
<4 \\
<4 \\
<4 \\
<4 \\
<4 \\
<4 \\
<4 \\
<4 \\
<4 \\
128 \\
<4 \\
8 \\
32 \\
64 \\
16 \\
<4 \\
16\end{array}$ & $\begin{array}{r}<4 \\
<4 \\
4 \\
16 \\
<4 \\
<4 \\
<4 \\
<4 \\
<4 \\
<4 \\
>256 \\
<4 \\
<4 \\
\text { N.A. } \\
\text { N.A. } \\
\text { N.A. } \\
\text { N.A. } \\
8\end{array}$ & $\begin{array}{r}<4 \\
4 \\
4 \\
8 \\
<4 \\
<4 \\
<4 \\
<4 \\
<4 \\
<4 \\
>256 \\
<4 \\
<4 \\
<4 \\
128 \\
>256 \\
32\end{array}$ \\
\hline
\end{tabular}

* Reciprocal of endpoint dilution.

N.A. $=$ Not available. be enlarged in eight cases, while one patient (Case 11) showed linear atelectasis of the lower lobe of the right lung and two (Cases 16 and 18) showed pleural effusion. Aseptic meningitis was found in five (Cases 1, 4, 5, 9 and 17).

The results of virological investigations are shown in Table II. Coxsackie B5 was isolated from the faeces of 12 patients, Coxsackie A9 in one case. Neutralizing antibodies, which were determined against the viruses occurring in Finland at the time in question, were found in all but one case against Coxsackie B5, while one-third of the patients had antibodies against Coxsackie A9 and B3.

All the patients recovered. The average period of treatment was three weeks, the range being from 11 to 34 days. In 12 cases follow-up examination was performed, on average seven months after discharge from hospital. In Case 8 the E.C.G. still showed a negative $T$ wave in leads II, III, aVF, and V3-6, while the remainder of these patients showed no appreciable electrocardiographic changes, and the heart was of normal size in all.

\section{Discussion}

Among the 12 patients from whom Coxsackie B5 virus was recovered from faeces samples five showed a fourfold increase in the titre of neutralizing antibodies against this virus, while the others had high antibody titres in both blood samples taken with a two-week interval. Often the patients have been ill for some time before admission and the antibody response has already reached its maximum.

In six cases attempts to isolate Coxsackie B5 virus failed, but four of these patients (Cases 9, 10,11, and 16) had high antibody titres, indicating the likelihood of Coxsackie B5 infection. One patient (Case 11) may have had both Coxsackie B5 and Coxsackie A9 infection. However, two patients (Cases 15 and 18) whose disease was not clinically distinguishable from that of the others showed no (Case 18) or only a very low (Case 15) titre of antibodies against Coxsackie B5, which suggests that their illness plausibly was not caused by Coxsackie B5 infection.

In the present series men were twice as numerous as women, which corresponds to the ratio previously reported (Gillett, 1959 ; Smith, 1966). The age distribution also agrees with earlier reports (Bradley, 1964).

In the clinical diagnosis of pericarditis attention is paid to chest pain aggravated by movement, respiration, coughing or swallowing, pericardial friction rub, electrocardiographic changes, and radiological changes in the size and shape of the heart. In the present series of 18 patients six showed all the above-mentioned criteria. As regards the various criteria, E.C.G. changes were present in all 18 cases, friction rub in 14, chest pain in 12, and enlargement of the heart in eight.

Since no electric potentials have been discovered in the pericardium the electrocardiographic changes in pericarditis are 
attributed to myocardial inflammation (Wolff and Grundfeld, 1963). For this reason it does not seem justifiable to divide the cardiac manifestations due to viral infection into pericarditis and myocarditis; it would be more reasonable to speak of myopericarditis and myocarditis (Smith, 1966).

Among the clinical findings in the present cases leucocytosis and raised A.S.T. and S.G.O.T. should also be mentioned. The occurrence of leucocytosis in seven patients corresponds to the observations made in previous series of viral pericarditis. The A.S.T. was elevated in three out of 16 patients investigated. The same phenomenon has previously been noted in certain cases of pericarditis due to Coxsackie B5 virus (Gillett, 1959 ; Hedlund et al., 1962; Pollen, 1963). The raised S.G.O.T. values in two patients seem to suggest severe myocarditis (Smith, 1966) or simultaneous anicteric hepatitis (Sun and Smith, 1966).

The pathogenesis of viral myopericarditis is not yet fully understood. Whether the heart muscle is affected directly or by some sensitivity or immunity reaction is still far from clear (Sanders, 1963). It has been suggested that the cardiac mani- festations in viral disease may include endocarditis, which may lead to valvular lesions (Burch and DePasquale, 1964 ; Smith, 1966). The part played by viral myopericarditis as the primary cause of aetiologically obscure persistent cardiomyopathies has not yet been clarified. Long-term follow-up studies might yield valuable information.

\section{REFERENCES}

Bing, H. I. (1933). Acta med. scand., 80, 29.

Bradley, E. C. (1964). Amer. Heart f., 67, 121.

Burch, G. E., and DePasquale, N. P. (1964). Amer. Heart F., 67, 721.

Fletcher, E., and Brennan, C. F. (1957). Lancet, 1, 913.

Gillett, R L (1959). New Engl 7. Med 261, 838.

Hedlund, P., Lycke, E., and Tibblin, G. (1962). Acta med. scand., 172, 323.

Jarcho, S. (1963). Amer. f. Cardiol., 11, 798

Javett, S. N., et al. (1956). F. Pediat., 48, 1.

Pollen, R. H. (1963). Amer. f. Cardiol., 12, 736

Sanders, V. (1963). Amer. Heart f., 66, 707.

Smith, W. G. (1966). Brit. Heart F., 28, 204.

Sun, N. C., and Smith, V. M. (1966). New Engl. f. Med., 274, $\$ 90$.

Weinstein, S. B. (1957). New Engl. F. Med., 257, 265.

Wolff, L, and Grundfeld, O. (1963). New Engl. F. Med., 268, 419.

\section{Preliminary Communications}

\section{Bone Marrow Colony-stimulating Activity of Sera in Infectious Mononucleosis}

Brit. med. F., 1968, 3, 99-101

\begin{abstract}
Cummary : From 44 to $100 \%$ of sera from patients with $\checkmark$ infectious mononucleosis exhibited the capacity to stimulate colony formation in vitro by mouse bone marrow cells. The proportion of sera with colonystimulating activity was highest in patients with a short fever period and developing low Paul-Bunnell titres. Patients with a more severe course of the disease generally displayed no, or only weak, colony-stimulating activity in their sera, and also had higher Paul-Bunnell titres. The level of serum colony-stimulating activity tended to fall in the convalescent stages of the disease.
\end{abstract}

When suitably stimulated certain mouse bone marrow cells can proliferate in semisolid agar cultures and form colonies of granulocytic and mononuclear cells (Bradley and Metcalf, 1966; Metcalf et al., 1967). Mouse serum has been shown to contain a factor (the colony-stimulating factor) which can stimulate the formation of such colonies (Robinson et al., 1967). This factor is a relatively heat stable, non-dialysable substance migrating electrophoretically in the post-albumin region and having a sedimentation constant of about 4-7S (Stanley et al., 1968). Levels of colony-stimulating factor in the serum are raised in mice with spontaneous or viral-induced leukaemia (Robinson et al., 1967 ; Metcalf and Foster, 1967a) and are temporarily raised after infection with at least one virus-the lactate dehydrogenase-elevating virus of Riley (Foster et al., 1968a).

A recent survey of human sera (Foster et al., 1968b) has shown that normal sera do not possess detectable colonystimulating activity for mouse bone marrow cells but that colony-stimulating activity is detectable in $15-70 \%$ of sera from patients with leukaemia and allied diseases, patients with proliferative disorders of leucopoiesis, and patients with acute non-bacterial infections.
In the course of the latter survey it was found that some sera from patients with infectious mononucleosis would stimulate colony formation. In the present study a detailed analysis has been made of serum colony-stimulating activity in such patients in relation to the clinical course of the disease and the occurrence of other abnormal findings in these patients.

\section{Patients and Sera}

The 38 patients with mononucleosis were young Swedish adults whose acute and convalescent sera were collected in 1966 and forwarded for diagnostic examination to the Department of Virology, National Bacteriological Laboratory, Stockholm. Either single (22 cases) or paired sera (16 cases) were taken from patients who fulfilled two criteria: (a) a positive Paul-Bunnell titre after absorption with guinea-pig kidney according to Davidsohn et al. (1951), and (b) a clinical course typical of mononucleosis with atypical mononuclear cells in the peripheral blood. The sera were kept for variable times at ambient temperature during shipment to Stockholm, and were kept at $-20^{\circ} \mathrm{C}$. thereafter. Thirty-nine of the 54 sera were subjected to heat inactivation at $56^{\circ} \mathrm{C}$. for 30 minutes before testing. Previous experiments have shown that serum retains its colony-stimulating activity after freeze-thawing and that the active factor is stable when heated at $60^{\circ} \mathrm{C}$. for 30 minutes. Normal human sera do not possess detectable colonystimulating activity (Foster et al., 1968b).

\section{Bone Marrow Culture Technique}

The bone marrow culture technique and the culture media have been described in detail elsewhere (Metcalf and Foster, 1967a). Bone marrow plugs were collected from a single femur shaft of three DBA/1 mice 2 to 3 months old and single cell suspensions were prepared by pipetting the plugs up and down in $5 \mathrm{ml}$. of bone marrow collecting fluid $(40 \mathrm{ml}$. of doublestrength modified Eagle's medium containing $20 \%$ foetal calf serum, $10 \mathrm{ml}$. of trypticase soy broth, and $50 \mathrm{ml}$. of water). 